UDC 631.582.5:633.85

\title{
COMPREHENSIVE ASSESSMENT OF CROPS ROTATIONS WITH DIFFERENT SATURATION OF OILSEEDS IN THE RIGHT-BANK FOREST-STEPPE
}

\section{Kvasnitska}

Article info

Received

27.04.2020

Accepted

24.06.2020

Khmelnitsky

State

Agricultural

Experimental

Station of the

Institute of

Forage and

Agriculture of

Podillya NAAS

Samchyky

village,

Starokostiantyniv

district,

Khmelnytsky

region,

31182, Ukraine

E-mail:

larusa7215@

ukr.net
Kvasnitska, L. (2020). Comprehensive assessment of crops rotations with different saturation of oilseeds in the Right-Bank Forest-Steppe. Scientific Horizons, 07 (92), 40-44. doi: 10.33249/2663-2144-2020-92-7-40-44.

Production of oilseeds for agricultural producers is one of the main sources of profitability, which allows to ensure efficient operation. The constant growth in demand for rapeseed, soybean and sunflower seeds both in Ukraine and on the world market has led to an expansion of the area occupied by these crops. The purpose of the research is to conduct a comparative assessment of short-rotation crop rotations saturated with oilseeds, and to determine the most effective options for the zone of sufficient moisture of the Right-Bank Forest-Steppe. Field research was conducted in a long-term stationary experiment at the Khmelnytsky State Agricultural Research Station of the Institute of Feed and Agriculture of Podillya NAAS during 2016-2018 on chernozem podzolic in five-field crop rotations, saturated with 40-60\% grain and 40-60\% oilseeds. According to research, the highest level of profitability of $157 \%$ was provided by crop rotation saturated with $40 \%$ oilseeds, of which $20 \%$ winter rape and $20 \%$ soybeans, the cost of which was the highest at the lowest cost of cultivation. The energy efficiency ratio was 4.57 conventional units. With the introduction of $40 \%$ of winter rape in crop rotation, oil harvest increased by $45 \%$, but other productivity indicators per hectare of crop rotation area decreased significantly.

High average yield of grain crops $-6.93 \mathrm{t} / \mathrm{ha}$, harvest of feed units -7.12 tons, digestible protein - 0.790 tons per hectare of crop rotation area at a level of profitability of $111 \%$ was obtained in crop rotation saturated with $60 \%$ grain and $40 \%$ oilseeds, of which $20 \%$ sunflower and $20 \%$ soybeans, under an alternative fertilizer system. The energy efficiency ratio was 3.52 conventional units. The use of only a mineral fertilizer system in an identical crop rotation set increased the energy efficiency of a hectare of crop rotation area.

Key words: crop rotation, soybean, sunflower, winter rape, economic and energy efficiency.

\section{КОМПЛЕКСНА ОЦІНКА СІВОЗМІН З РІЗНИМ НАСИЧЕННЯМ ОЛІЙНИМИ КУЛЬТУРАМИ В УМОВАХ ПРАВОБЕРЕЖНОГО ЛІСОСТЕПУ}

\section{Л. С. Квасніцька}

Хмельницька державна сільськогосподарська дослідна станція Інституту кормів та сільського господарства Поділля НААН

с. Самчики, Старокостянтинівський район, Хмельницька область, 31182

Виробництво олійних культур для сільськогосподарських товаровиробників є одним із основних джерел формування прибутковості, що дає змогу забезпечити ефективну діяльність. Постійне зростання попиту на насіння ріпаку, сої, соняшнику не лише в Україні, а й на світовому ринку сприяло 
розширенню площ, зайнятих цими культурами. Мета досліджень - провести порівняльну оцінку короткоротаційних сівозмін, насичених олійними культурами, та визначити найефективніші їх варіанти для зони достатнього зволоження Правобережного Лісостепу. Польові дослідження проведені протягом 2016-2018 рр. в умовах Хмельницької держсавної сільськогосподарської дослідної станції Інституту кормів та сільського господарства Поділля НААН на чорноземних опідзолених трунтах у п'ятипільних сівозмінах з насиченням на 40-60 \% зерновими та 40-60\% олійними культурами.

За результатами досліджень було встановлено, що найвищий рівень рентабельності $157 \%$ забезпечила сівозміна насичена на 40 \% олійними культурами, з них $20 \%$ ріпаку озимого та $20 \%$ сої, вартість виробленої продукиї у якій була найбільшою за нижчих витрат на вирощування. Коефіцієнт енергетичної ефективності становив 4,57 умовних одиниць. За уведення у сівозміну $40 \%$ ріпаку озимого збільшився збір олії на 45 \%, однак суттєво знизились інші показники продуктивності гектара сівозмінної площі.

Високу середню урожайність зернових культур - 6,93 m/2a, збір кормових одинищь - 7,12 m, перетравного протеїну - 0,790 $\mathrm{m}$ з гектара сівозмінної площі за рівня рентабельності 111 \% отримано у сівозміні насиченій на 60 \% зерновими та 40 \% олійними культурами, з них 20 \% сонямнику та $20 \%$ сої, за альтернативної системи удобрення. Коефіиіснт енергетичної ефективності становив 3,52 умовних одиниць. Застосування лише мінеральної системи удобрення у ідентичній за набором культур сівозміні підвищило показники енергетичної ефективності гектара сівозмінної площі.

Ключові слова: сівозміна, соя, соняшник, ріпак озимий, продуктивність, економічна та енергетична ефективність.

\section{Вступ}

Сучасне високотоварне сільськогосподарське виробництво неможливе без суворого регламентованого комплексу технологій і організаційногосподарських заходів, які відповідають виробничій спеціалізації господарств і прийнятій системі землеробства. Адже високі врожаї з одночасним підвищенням родючості грунту отримують лише за оптимальної структури посівних площ, набору, співвідношення і чергування культур у різноротаційних сівозмінах (Shuvar, 1998; Boiko.et al., 2016; Kaminskyi et al., 2018).

Нині потрібно обгрунтовано підійти до економічних питань організації аграрного виробництва, враховуючи світову кон'юнктуру і аналіз зовнішніх ринків збуту сільськогосподарської продукції, дотримуючись водночас науково обгрунтованих підходів чергування культур у сівозміні. Лише за наявності раціональних сівозмін формуються умови для планового застосування технологій на кожному полі, зростає продуктивність кожної культури. Беззмінне їх вирощування різко знижує врожайність, родючість грунту, погіршує фітосанітарний стан його i посівів порівняно із сівозміною. Правильно складена сівозміна має велике значення для підвищення культури землеробства, росту врожайності кожної культури i рентабельності землеробства (Kaminskyi, 2015; Kaminskyi, 2016; Kernasiuk, 2016).

Значну роль у розвитку аграрного напрямку економіки України займають зернові та олійні культури. Зерновий клин представлено трьома основними культурами - пшеницею, ячменем та кукурудзою. Олійний напрям зосереджується на вирощуванні насіння соняшнику, сої та ріпаку. Щорічні надходження від реалізації зернових і олійних культур становлять 6,5 та 1,7 млрд доларів США, відповідно (Karamushka et al., 2018).

Таким чином, метою наших досліджень було проведення порівняльної оцінки короткоротаційних сівозмін, що насичені олійними культурами, за різних систем удобрення та визначення найбільш ефективних їх варіантів для зони достатнього зволоження Правобережного Лісостепу.

\section{Матеріали та методи}

Польові дослідження проводили в тривалому стаціонарному досліді на Хмельницькій ДСГДС ІКСГП НААН протягом 2016-2018 pp. на чорноземі опідзоленому в чотирьох сівозмінах, насичених на 40-60\% зерновими та 40-60\% технічними культурами (табл. 1).

Грунт дослідної ділянки - чорнозем опідзолений середньосуглинковий. Розміщення варіантів у досліді систематичне, посівна площа ділянки - $174 \mathrm{~m}^{2}$, облікова - $100 \mathrm{~m}^{2}$, повторність триразова. У досліді посів проводили сортами та гібридами сільськогосподарських культур, що занесені до Державного реєстру сортів рослин, 
придатних до поширення в Україні. Технології вирощування досліджуваних культур були загальноприйняті для зони достатнього зволоження Правобережного Лісостепу України.

Показники продуктивності сівозмін здійснювали із врахуванням виходу основної та побічної продукції на 1 га ріллі, що перераховували у зернові одиниці за коефіцієнтами В. Д. Гревцова (Grevzov, 1991), а кормові одиниці та перетравний протеїн визначали за методикою M.М. Карпуся «Деталізована поживність кормів зони Лісостепу України» (Karpys, 1995).

Розрахунки енергетичної ефективності окремих культур i сівозмін проводили за загальноприйнятими методиками (Tarariko et al., 2001), а економічну ефективність визначали за технологічними картами та нормативними матеріалами господарств вищезазначеної зони.

Математично-статистичну обробку експериментальних даних обраховано методом дисперсійного аналізу 3 використанням програмних засобів Microsoft Excel.

Таблиия 1. Структура посівних площ та система удобрення у п'ятипільних сівозмінах, 2016-2018 pp.

\begin{tabular}{|c|c|c|c|c|c|c|c|c|c|c|c|}
\hline \multirow{3}{*}{ 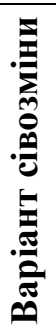 } & \multicolumn{8}{|c|}{ Структура посівних площ, \% } & \multirow{2}{*}{\multicolumn{3}{|c|}{$\begin{array}{c}\text { Внесено на гектар } \\
\text { сівозмінної площі } \\
\text { діючої речовини, кг }\end{array}$}} \\
\hline & \multirow{2}{*}{$\begin{array}{l} \\
\\
\vdots \\
0\end{array}$} & \multicolumn{3}{|c|}{ з них } & \multirow{2}{*}{ 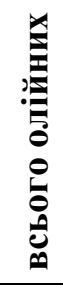 } & \multicolumn{3}{|c|}{ з них } & & & \\
\hline & & 罗 & $\frac{\rho}{\sum_{0}^{0}}$ & 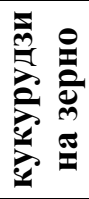 & & :- & 递 & 岂 & $\mathbf{N}$ & $\mathbf{P}_{2} \mathbf{O}_{5}$ & $\mathbf{K}_{\mathbf{2}} \mathbf{O}$ \\
\hline 1 & 60 & 20 & 20 & 20 & 40 & 20 & - & 20 & 62 & 52 & 58 \\
\hline 2 & 60 & 20 & 20 & 20 & 40 & 20 & 20 & - & 74 & 54 & 62 \\
\hline 3 & 40 & 40 & - & - & 60 & 20 & 40 & - & 80 & 52 & 60 \\
\hline 4 & 60 & 20 & 20 & 20 & 40 & 20 & - & 20 & 62 & 52 & 58 \\
\hline
\end{tabular}

Примітка: у варіанті 5 у кожному полі щорічно побічну продукцію заробляли на добриво та вносили компенсуючу дозу азоту $\mathrm{N}_{10} / \mathrm{T}$ (альтернативна система удобрення).

\section{Результати досліджень та обговорення}

Соняшник у зерно-просапній сівозміні вирощували після пшениці озимої. Урожайність його у досліді становила 3,19-3,99 т/га (табл. 2). Відмічено суттєве підвищення іiї у варіанті 4, де заорювали побічну продукцію попередника на добриво, за рахунок збільшення маса 1000 насінин на $8 \%$ та маси насіння 31 рослини - на $4 \%$ (варіант 2 порівняно із варіантом 1). Більша кількість доступної вологи у грунті у цьому варіанті забезпечила кращі умови для росту та розвитку рослин культури.

Попередниками сої у досліді були кукурудза на зерно, ячмінь ярий та ріпак озимий. Кукурудза на зерно забезпечила найвищий рівень урожайності культури. Аналіз структури урожаю сої засвідчив, що найбільша кількість насінин на 1 рослині - 34,2 шт. та масу 1000 насінин - 170,9 г була у варіанті 4 за альтернативної системи удобрення.
Суттєве зниження урожайності сої (18\%) отримали за вирощування після ріпаку озимого у зерно-ріпаковій сівозміні 4. Тут відмічено погіршення санітарного стану посівів, пригнічення розвитку рослин. Висота рослин сої знизилася на $23 \%$, маса 1000 насінин - на $9 \%$ та на $22 \%$ менше сформувалося насінин у бобі (варіант 3 порівняно з варіантом 4).

Урожайність ріпаку озимого у досліді становила 2,61-3,26 т/га. Повернення його у сівозміну через 2 роки знизило урожайність на $6 \%$, через 1 рік - на $17 \%$, за цього відмічено зменшення густоти посіву на 21 та $36 \%$, кількості насінин на 1 рослині на 8 та $14 \%$, відповідно. Ріпак як попередник пшениці озимої забезпечив ії урожайність на рівні 6,96 т/га.

Продуктивність короткоротаційних сівозмін змінювалася залежно від набору, співвідношення і розміщення зернових та олійних культур та системи удобрення у сівозміні. Найбільший збір з гектара сівозмінної площі зерна $-4,16$ т, олії $-0,50$ т за рівня рентабельності $111 \%$ отримано у сівозміні 4 , насиченій на $60 \%$ зерновими та $40 \%$ олійними культурами, 3 них $20 \%$ соняшнику та $20 \%$ сої, за альтернативної системи удобрення (табл. 3). 
Таблиия 2. Урожайність сільськогосподарських культур у сівозмінах, 2016-2018 pp.

\begin{tabular}{|c|c|c|c|c|c|c|c|}
\hline \multirow[b]{2}{*}{ 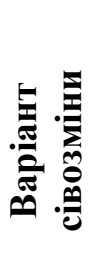 } & \multirow[b]{2}{*}{$\begin{array}{c}\text { Середня } \\
\text { урожайність } \\
\text { зернових, т/га }\end{array}$} & \multicolumn{6}{|c|}{ Урожайність культур, т/га } \\
\hline & & : & :8; & 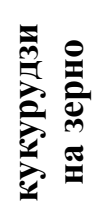 & 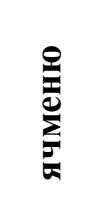 & 递 & 焉 \\
\hline 1 & 6,63 & 6,76 & 2,42 & 7,78 & 5,36 & - & 3,20 \\
\hline 2 & 6,73 & 6,78 & 2,38 & 7,80 & 5,62 & 3,26 & - \\
\hline 3 & 6,49 & 6,49 & 2,07 & - & - & 2,73 & - \\
\hline 4 & 6,93 & 6,96 & 2,68 & 8,27 & 5,56 & - & 3,80 \\
\hline \multicolumn{2}{|r|}{$\mathrm{HIP}_{05}$} & 0,11 & 0,07 & 0,03 & 0,12 & 0,02 & 0,05 \\
\hline
\end{tabular}

Таблиия 3. Показники продуктивності та економічної ефективності сівозмін, 2016-2018 pp.

\begin{tabular}{|c|c|c|c|c|c|c|c|c|c|c|c|}
\hline \multirow{3}{*}{ 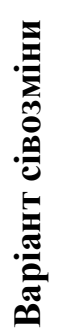 } & \multicolumn{8}{|c|}{ Збір з гектара сівозмінної площі, т } & \multicolumn{2}{|c|}{ Собівартість, грн/т } & \multirow{3}{*}{ 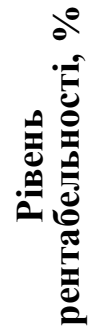 } \\
\hline & \multirow{2}{*}{ 营 } & \multirow{2}{*}{ 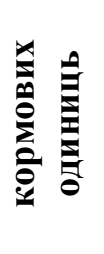 } & \multirow{2}{*}{ 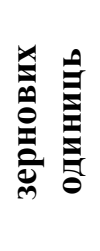 } & \multirow{2}{*}{ 影 } & \multirow{2}{*}{ 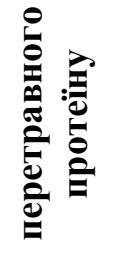 } & \multicolumn{3}{|c|}{ насіння } & \multirow{2}{*}{$\frac{\pi}{0}$} & \multirow{2}{*}{ 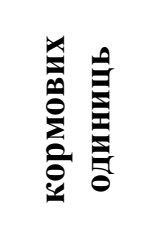 } & \\
\hline & & & & & & 紊 & 焉 & : & & & \\
\hline 1 & 3,98 & 7,91 & 6,95 & 0,43 & 0,750 & - & 0,64 & 0,40 & 2595,43 & 2071,34 & 125 \\
\hline 2 & 4,04 & 8,71 & 6,67 & 0,37 & 0,696 & 0,65 & - & 0,48 & 2489,00 & 1871,16 & 157 \\
\hline 3 & 2,60 & 6,68 & 5,89 & 0,54 & 0,653 & 1,09 & - & 0,41 & 2647,55 & 2487,53 & 140 \\
\hline 4 & 4,16 & 7,12 & 6,42 & 0,50 & 0,790 & - & 0,76 & 0,54 & 2779,69 & 2536,81 & 111 \\
\hline
\end{tabular}

Слід зазначити, що зниження показників економічної ефективності у цій сівозміні відбулося через збільшення витрат коштів на гектар сівозмінної площі за рахунок компенсуючої дози азоту для розкладання побічної продукції.

Введення у сівозміну замість соняшнику ріпаку озимого збільшило збір кормових одиниць на $10 \%$, однак забезпеченість ї перетравним протеїном зменшилася на $27 \%$ (варіант 2 порівняно з варіантом 1).

У сівозміні (вар. 3) насиченій на $20 \%$ соєю та по $40 \%$ ріпаком озимим і пшеницею озимою одержали найбільший збір продовольчого зерна (2,60 т/га сівозмінної площі). Однак, збір з гектара сівозмінної площі кормових одиниць становив 6,68 т, що на $23 \%$ нижче, ніж у варіанті 2.

Слід зазначити, що сівозміни насичені олійними культурами - високорентабельні. Однак, найвищий рівень рентабельності $157 \%$ забезпечила сівозміна 3, насичена на $60 \%$ зерновими та по $20 \%$ ріпаком озимим та соєю, вартість виробленої продукції, у якій на $10 \%$ була більшою за нижчих витрат на вирощування (вар. 3 порівняно 3 вар. 2). Собівартість зерна становила 2489,00 грн/т, кормових одиниць 1871,16 грн/т.

Найвищі показники енергетичної ефективності відмічено у сівозміні 1 , насиченій на $60 \%$ зерновими та $40 \%$ олійними культурами, 3 них $20 \%$ соняшнику та $20 \%$ сої, за мінеральної системи удобрення, де енергетичні витрати на вирощування продукції були найменшими 24,1 ГДж/га, що дозволило отримати найвищий Кее - 8,39 умовних одиниць (табл. 4). Слід зазначити, що саме у цій сівозміні отримали найменший показник енергетичних витрат на 1 тонну зерна - 6,06 ГДж та кормових одиниць 3,00 ГДж. 
Таблиия 4. Енергетична оцінка сівозмін, 2016-2018 pp.

\begin{tabular}{|c|c|c|c|c|c|}
\hline \multirow{3}{*}{$\begin{array}{c}\text { Варіант } \\
\text { сівозміни }\end{array}$} & \multirow{3}{*}{$\begin{array}{c}\text { Енергоємність } \\
\text { врожаю, ГДж/га }\end{array}$} & \multicolumn{3}{|c|}{ Енерговитрати, ГДж } & \multirow{3}{*}{$\begin{array}{l}\text { Коефіціснт } \\
\text { енергетичноі } \\
\text { ефективності }\end{array}$} \\
\hline & & \multirow[b]{2}{*}{ на 1 га } & \multicolumn{2}{|c|}{ на $1 \mathrm{~T}$} & \\
\hline & & & зерна & $\begin{array}{c}\text { кормових } \\
\text { одиниць }\end{array}$ & \\
\hline 1 & 202,2 & 24,1 & 6,06 & 3,00 & 8,39 \\
\hline 2 & 169,9 & 37,2 & 9,21 & 4,18 & 4,57 \\
\hline 3 & 134,7 & 24,6 & 9,46 & 3,48 & 5,48 \\
\hline 4 & 229,2 & 36,7 & 8,82 & 5,09 & 6,24 \\
\hline
\end{tabular}

\section{Висновки}

В умовах достатнього зволоження Правобережного Лісостепу України сівозміни насичені на 40-60\% олійними культурами високорентабельні. Однак, найвищий рівень рентабельності $157 \%$ забезпечила сівозміна насичена на $20 \%$ ріпаком озимим та $20 \%$ соєю, вартість виробленої продукції у якій на 10 \% була більшою за менших витрат на вирощування. Коефіцієнт енергетичної ефективності становив 4,57 умовних одиниць.

За уведення у сівозміну $40 \%$ ріпаку озимого збільшився збір олії на $45 \%$, однак суттєво зменшився вихід з гектара сівозмінної площі: зерна - на $35 \%$, зернових - на $11 \%$ та кормових - на $23 \%$ одиниць, перетравного протеїну - на $6 \%$.

Високу середню урожайність зернових культур - 6,93 т/га, збір кормових одиниць - 7,12 т, перетравного протеїну $-0,790$ т 3 гектара сівозмінної площі за рівня рентабельності $111 \%$ отримано у сівозміні насиченій на $60 \%$ зерновими та $40 \%$ олійними культурами, 3 них $20 \%$ соняшнику та $20 \%$ сої, за альтернативної системи удобрення. Коефіцієнт енергетичної ефективності становив 6,24 умовних одиниць. Застосування лише мінеральної системи удобрення у ідентичній за набором культур сівозміні підвищило показник Кее до 8,39 умовних одиниць.

\section{References}

Boiko, P. I., Litvinov D. V., Demydenko O. V., Shapoval, I. S. \& Kovalenko, N. P. (2016). Produktyvnist silskohospodarskykh kultur u riznorotatsiinykh sivozminakh na typovykh chornozemakh [Productivity of agricultural crops in rotational crop rotations on typical chernozems]. Visnyk ahrarnoi nauky, 12, 11-16. [in Ukrainian].

Grevtsov, V. D. (Ed.). (1991). Spravochnik po planirovaniyu $\mathrm{v}$ agropromyshlennom komplekse [Agribusiness planning handbook]. Kiyev: Urozhay [in Russian].

Kaminskyi, V. F. (2015). Sivozmina yak osnova staloho zemlekorystuvannia ta prodovolchoi bezpeky
Ukrainy [Crop rotation as a basis for sustainable land use and food security of Ukraine]. Zemlerobstvo, 2, 3-13 [in Ukrainian].

Kaminskyi, V. F. (2016). Naukovi zasady biolohichnoho zemlerobstva $\mathrm{v}$ umovakh zminy klimatu [Scientific principles of organic farming in the context of climate change]. Zemlerobstvo, 1, 3-11 [in Ukrainian].

Kaminskyi, V. F., Shevchenko, I. P. \& Kolomiiets, L. P. (2018). Naukovo-metodychne zabezpechennia okhorony zemel silskohospodarskoho pryznachennia yak peredumova staloho rozvytku ahropromyslovoho kompleksu Ukrainy [Scientific and methodological support for the protection of agricultural lands as a prerequisite for sustainable development of the agro-industrial complex of Ukraine]. Visnyk ahrarnoi nauky, 1, 510. doi: 10.31073/agrovisnyk201801-01 [in Ukrainian].

Karamushka, O. M. \& Moroz, S. I. (2018). Analiz vyrobnytstva zernovykh ta oliinykh kultur v Ukraini [Analysis of grain and oilseeds production in Ukraine]. Efektyvna ekonomika, 10. doi: 10.32702/2307-2105-2018.10.41 [in Ukrainian].

Karpus, M. M., Slavov, V. P., Lapa, M. A. \& Martyniuk, H. M. (1995). Detalizovana pozhyvnist kormiv zony Lisostepu Ukrainy [Detalizovana pozhyvnist kormiv zony Lisostepu Ukrainy]. Kyiv: Ahrarna nauka [in Ukrainian].

Kernasiuk, Yu. (2016). Zovnishnoekonomichnyi oriientyr dlia ukrainskoho ahroeksportu [Foreign economic landmark for Ukrainian agro-export]. Ahrobiznes sohodni, 4, 15-17 [in Ukrainian].

Shuvar, I. A. (1998). Naukovi osnovy sivozmin intensyvno-ekolohichnoho zemlerobstva [Scientific bases of crop rotations of intensive ecological agriculture]. Lviv: Kameniar [in Ukrainian].

Tarariko, Yu. O., Nesmashna, O. Yu. \& Hlushchenko, L. D. (2001). Enerhetychna otsinka system zemlerobstva i tekhnolohii vyroshchuvannia silskohospodarskykh kultur [Energy assessment of agricultural systems and technologies of growing crops]. Kyiv : Nora-Print [in Ukrainian]. 